\title{
If you build it, they will come: A case-study of how FSU Libraries grew engineering services through targeted rebranding and outreach for a multi-institution college of engineering
}

\author{
Denise Amanda Wetzel, Florida A\&M University/Florida State University
}

Denise A. Wetzel joined Florida State University Libraries in January 2018. She holds a B.H. in Interdisciplinary Studies from the Pennsylvania State University and a Masters in Library and Information Studies from the University of Alabama. Currently, Denise is pursuing a Masters in Aquatic Environmental Science with Florida State University's Department of Earth, Ocean, and Atmospheric Science. She is a member of Atmospheric Science Librarians International (ASLI), the American Meteorological Society (AMS), the American Society of Engineering Education/Engineering Libraries Division (ELD), the International Association of Aquatic and Marine Science Libraries and Information Centers/SAIL, and the American Library Association (ALA). Before joining FSU, Denise worked for Mississippi State University Libraries, the Alabama Public Library Service, and as an ESL teacher. Her research interests include undergraduate information literacy, patent searching in STEM, terminology usage disparities by researchers across STEM disciplines, and meteorology resources and their use.

\section{Kelly Grove, Florida A\&M University/Florida State University}

Kelly Grove has been with Florida State University Libraries since January 2017. She serves as a subject librarian for multiple departments and colleges at FSU. She holds a B.S. in Geology from the University of Idaho and a Masters in Library and Information Science from the University of Alabama. Kelly is currently pursuing a Masters in Geographic Information Science from Florida State University. Her research interests include STEM information literacy, information literacy, the cost of doing research, academic librarians and meeting the needs of students on the Autism Spectrum, and open educational resources (OER). 


\title{
If you build it, they will come: A case-study of how FSU Libraries grew engineering services through targeted rebranding and outreach for a multi-institution college of engineering
}

\begin{abstract}
The College of Engineering (COE) was established as a joint collegiate program serving two universities in Tallahassee, FL: Florida A \& M University (FAMU) and the Florida State University (FSU). The COE campus is located at a separate, neutral location between the two main campuses in an area called Innovation Park. Library services for the COE are provided through FSU Libraries, which includes a tiny physical COE Library space, and the papers' authors serve as the two COE Librarians. Due to the unique challenges related to serving a multiinstitutional, student, staff, faculty, and researcher populations in a physically separate campus location, FSU Libraries has had to rethink the traditional academic library service model.

From rebranding outreach materials to incorporate neutral non-institutionally affiliated colors, to moving the location of office hours from the physically tight COE Library space to a more adaptable atrium location, to troubleshooting access and its associated technical problems for information provided by FAMU, to reinvigorating what it means to be a COE Librarian, the authors share their methods and steps undertaken to fully assimilate themselves as leaders of information needs for all COE students, staff, faculty, and researchers. This case-study examines both the successful innovations and the failed attempts to re-energize the relationship between COE constituents and Libraries. The authors also touch on how they challenged what it means when the COE Library "holds a workshop" and how building these new relationships support the COE's staff-initiated conversations and opportunities on how to better reach COE students, faculty, and researchers. Even with the unique COE situation presented by the authors, this paper has an opportunity to serve as a guide and idea generator for other COE Librarians as they work within the boundaries of their own COE constraints.
\end{abstract}

Introduction

The FAMU-FSU College of Engineering (COE) is a unique collegiate experience that allows students from both Florida A \& M University (FAMU) and the Florida State University (FSU) to attend a single, joint college located in Tallahassee, Florida. This COE is dedicated to both education and research across multiple engineering areas, allowing students and faculty the opportunity to engage in innovative research skills. The COE Library is a tight space confined in two rooms within the COE building itself, managed by librarians and staff from FSU Libraries, while employing student assistants from both institutions. This case study explores how FSU's COE Librarians have used this distinctive opportunity to create a model of embedded librarianship in both relationships and improve outreach to make an impact on the lives of the faculty, staff, and students they work with. Both authors acknowledge they are employed by FSU Libraries and co-wrote this paper from the mindset of FSU employees providing outreach and engineering support for a multi-institution college. Due to the difference in library size and staffing models between FSU Libraries and FAMU Libraries, outreach efforts for COE primarily come from FSU Libraries due to the capacity to innovate new services, workshops, and outreach 
efforts. Cross-institutional meetings between FSU Libraries and FAMU Libraries have taken place previously in an effort to further expand services, but at this time there is not a joint approach in effect. In order to initiate readers to the uniqueness of this case study, the authors began with a comparative analysis of shared and multi-institutional engineering programs across the United States.

Comparative analysis of joint engineering schools

In an effort to compare the FAMU-FSU College of Engineering to other similar programs the authors conducted a series of searches using an individual comparative contrast approach to better understand how other shared colleges and/or programs are created and maintained by two or more separate universities. An individual comparative contrast involves comparing two or more instances for the purpose of examining the specifications that are both unique and similar between the instances of interest [1]. Results were compiled using the databases ERIC (a ProQuest product), Web of Science Core Collection (a Clarivate Analytics product), and Education Source (an EBSCOhost product) and the search string "(("joint use" OR joint-use) OR consortium OR partnership OR shared) AND (major OR degree) AND (university OR college) AND engineering" with a limit of articles published for no earlier than January 1, 2005, from a peer reviewed journal, and written in English. Once the initial results were obtained the authors screened the articles for appropriateness using the articles' title, abstract, and keywords to determine its relevance to the topic. After conducting this series of searches the authors found ten articles, once duplicates were removed from the list, that appeared to coincide to the focus of this paper based on these criteria. After reading these ten articles, eight were excluded due to lack of relevance as the full text revealed the papers foci to be on non-relevant topics regarding joint institutional engineering programs. The number of initial search results, notes on these results, and number of post screening results can be found in Table 1. 


\begin{tabular}{|l|l|l|l|}
\hline Database & $\begin{array}{l}\text { Initial Number } \\
\text { of Results }\end{array}$ & Notes on the results & $\begin{array}{l}\text { Number of Results } \\
\text { Post Screening }\end{array}$ \\
\hline ERIC & 67 & $\begin{array}{l}\text { Many results focus on teaching theory } \\
\text { within STEM. Articles about partnerships } \\
\text { between schools and private industries or } \\
\text { community partners. }\end{array}$ & 3 \\
\hline $\begin{array}{l}\text { Web of } \\
\text { Science }\end{array}$ & 151 & $\begin{array}{l}\text { Many results are about schools outside the } \\
\text { U.S. There are many articles talking about } \\
\text { partnerships with private industries and } \\
\text { schools. Many results focus on teaching } \\
\text { theory within STEM. Articles about } \\
\text { preparing students for the workforce }\end{array}$ & 2 \\
\hline $\begin{array}{l}\text { Education } \\
\text { Source }\end{array}$ & 211 & $\begin{array}{l}\text { Many results are about schools outside the } \\
\text { U.S. There are many articles talking about } \\
\text { partnerships with private industries and } \\
\text { schools. Papers focusing on non- } \\
\text { engineering majors. Many articles focus } \\
\text { on dual degree programs that are within } \\
\text { the same institution. }\end{array}$ & 5 \\
\hline
\end{tabular}

(Table 1: Eric, Web of Science, and Education Source Databases' Search Results)

Additionally the authors searched for individual programs' websites that showed a similarity to the FAMU-FSU COE program using the advanced search setting in Google with the search strings, "engineering college university "joint engineering institution " site:.edu" and "joint engineering institution college OR university -"joint -degree" site:.edu". The first search resulted in only two results, both leading back to the FAMU-FSU COE website. However, the second search came back with about 11,000,000 results. As the relevancy of the results diminished the authors only went through the links supplied in the first two pages equaling 21 website links. Of the 21 results four were for the FAMU-FSU COE website (this was attributed to the browsers cookie history), four links were ads supplied by an .edu domain, five links were for a dual degree program where the same institution grants two degrees to those in the program, and one link showed a joint program that has yet to be accredited by the Accreditation Board for Engineering and Technology (ABET). These 14 links were then excluded from this review, leaving seven webpages to examine. For the purposes of this case-study, we excluded all FAMU-FSU COE results.

Upon reviewing the articles collected from the databases and the Google search the authors found two common themes in the joint-institutional engineering programming landscape. First, a prevalence of international joint school programs between a school located in the United States and other countries was found, as shown in Table 2. In these programs' students are offered a specialized engineering program in their home country conducted in English. The students are usually given the opportunity to apply and transfer to the United States-based partner institution, usually after completing their second year within the program. Two examples include both The 
University of Michigan - Shanghai Jiao Tong University Joint Institute and The University of Pittsburgh - Sichuan University Partnership [2,3]. However, there are some novel international joint programs even within this category of results, such as with the Joint Engineering Co-op Institute, a partnership between The University of Cincinnati and China's Chongqing University. This particular program allows students from both institutions to obtain study abroad experiences through students' studies in both countries. Upon graduation these students receive a degree from both institutions [4]. Additionally, Georgia Institute of Technology's School of Mechanical Engineering partners with Germany's University of Stuttgart to create a joint master's program in mechanical engineering. These students spend a year at each school and upon completion of their program, graduate with a Master's Degree in Mechanical Engineering granted by both schools [5].

The second type of program that appeared in the two searches is the 3-2 programs. A 3-2 program describes how students apply to what is called their "home institution," typically a smaller school with no dedicated engineering degree where the students can enroll in their general education and pre-engineering coursework for two - four years. Usually around a student's third year they will then apply to the joint engineering program. If accepted, the students then transfer to a larger school with a full engineering program and complete their engineering coursework. Once finished with their engineering coursework the students are then awarded two Bachelor's Degrees, one from their home institution and one from the engineering degree granting institution [6-8]. It appears to be commonplace for students to obtain a Bachelor's Degree in subjects such as math, physics, or chemistry, however the program with the University of Columbia gives those who obtain a Bachelor's of Arts in a liberal arts field a pipeline into the field of engineering [7].The oldest 3-2 program the authors were able to identify dates originated back in 1969 between Georgia Institute of Technology (Georgia Tech), the Atlanta University Center (AUC), a consortium of five historically black colleges, and nine other schools. This partnership between Georgia Tech and the AUC originated with the objective of increasing minorities within the field of engineering [9]. 


\begin{tabular}{|c|c|c|}
\hline American Institution & Foreign Institution & Link \\
\hline The University of Michigan & $\begin{array}{l}\text { Shanghai Jiao Tong } \\
\text { University (China) }\end{array}$ & $\begin{array}{l}\text { https://www.engin.umich.edu/ } \\
\text { admissions/international/joint } \\
\text {-institute/ }\end{array}$ \\
\hline The University of Cincinnati & $\begin{array}{l}\text { Chongqing University } \\
\text { (China) }\end{array}$ & $\begin{array}{l}\text { https://ceas.uc.edu/real-world- } \\
\text { learning/global- } \\
\text { opportunities/joint- } \\
\text { engineering-co-op- } \\
\text { institute.html }\end{array}$ \\
\hline $\begin{array}{l}\text { Georgia Institute of } \\
\text { Technology (School of } \\
\text { Mechanical Engineering) }\end{array}$ & $\begin{array}{l}\text { University of Stuttgart } \\
\text { (Germany) }\end{array}$ & $\frac{\text { http://me.gatech.edu/featured }}{\text { jointmsmestuttgart }}$ \\
\hline The University of Pittsburgh & Sichuan University (China) & $\begin{array}{l}\text { http://www.news.pitt.edu/Pitt } \\
\text { Sichuan_Partnership }\end{array}$ \\
\hline
\end{tabular}

(Table 2: Examples of joint engineering programs between an institution in the U.S. and an international institution)

\begin{tabular}{|c|c|c|}
\hline $\begin{array}{l}\text { Engineering Degree } \\
\text { Granting Institution }\end{array}$ & $\begin{array}{l}\text { Number of Partner } \\
\text { Institution }\end{array}$ & Link \\
\hline $\begin{array}{l}\text { Georgia Institute of } \\
\text { Technology }\end{array}$ & 14 & See bibliography [8] \\
\hline $\begin{array}{l}\text { Illinois Institute of } \\
\text { Technology }\end{array}$ & 7 & https://web.iit.edu/ugaa/joint-programs \\
\hline Columbia University & 94 & $\begin{array}{l}\underline{\text { https://undergrad.admissions.columbia.edu/ }} \\
\underline{\text { sites/default/files/combined_plan_affiliates }} \\
\text { 2019-2020_final.pdf }\end{array}$ \\
\hline $\begin{array}{l}\text { North Carolina State } \\
\text { University }\end{array}$ & 10 & $\begin{array}{l}\text { https://www.engr.ncsu.edu/admissions/tran } \\
\text { sfer-admissions/partnerships/ }\end{array}$ \\
\hline
\end{tabular}

(Table 3: Examples of consortium based 3-2 engineering programs)

Background on the FAMU-FSU College of Engineering

The FAMU-FSU College of Engineering (COE) is a joint engineering school for both the Florida A\&M University (FAMU) and the Florida State University (FSU) undergraduate and graduate students in Tallahassee, Florida. On February 11, 1982 the Presidents of both FAMU and FSU, along with the Florida Board of Regents Chancellor Barbra Newell signed a proposal to work cooperatively to create a single educational space for engineering students in Tallahassee; the proposal was approved and given an initial budget on February 13, 1982 at the subsequent 
Florida Board of Regents meeting in Tampa, Florida [10]. This joint COE was a unique response to the need for more engineering education opportunities in the State of Florida. This one-of-akind multi-institutional space allows for a focus on bringing more minorities and women into the engineering fields.

The FAMU-FSU COE is located in Innovation Park area of Tallahassee, a location less than three miles from either university and is home to many research labs [11]. What could have been a problem of constant shuffling between campuses for faculty, staff, and students became a solution through the decision to build the $\mathrm{COE}$ in this neutral space. Official groundbreaking for the first of two COE buildings occurred on May 29, 1986, with the second building completed in 1998. Both buildings are connected by an enclosed breezeway and are endearingly called, Building A and Building B.

Students, faculty, and staff come from both institutions in order to create this singular College experience for all. Students earn Bachelor's Degrees in Chemical, Biomedical, Civil, Environmental, Electrical, Computer, Industrial, Manufacturing, and Mechanical Engineering; graduate programs award both Master of Science (MS) degrees and Doctor of Philosophy (PhD) degrees in Biomedical, Civil, Chemical, Electrical, Industrial, and Mechanical engineering fields. With approximately 2500 students in the COE bachelor, master, and doctoral degree-seeking programs as of the 2018-2019 academic school year, the College has come a long way over the past 33 years [12],[13]. As of December 2019, the total faculty and staff count for the COE stood at 154 members across five departments. Table 4 shows the total number of individuals on the blue line, with a breakdown of classification in either the tenure-track faculty, teaching faculty, or research faculty roles in the colors indicated underneath.

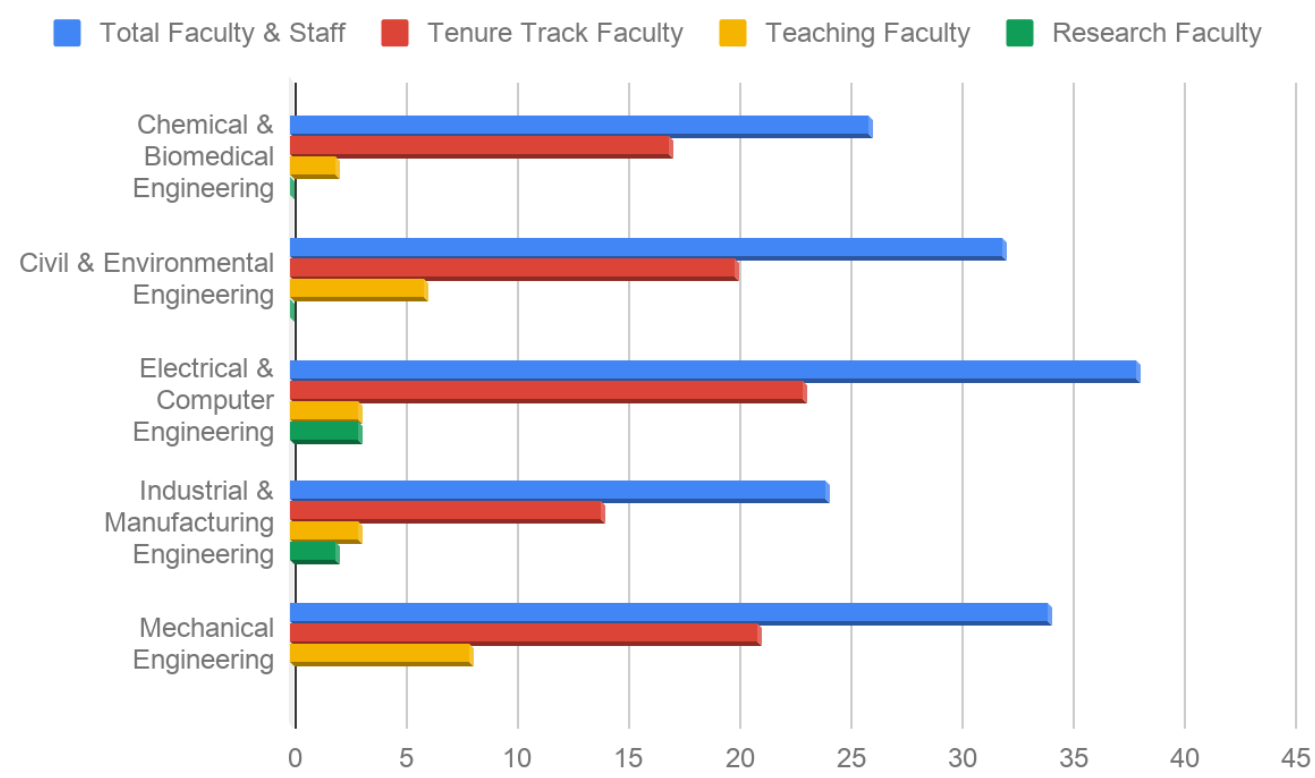

(Table 4: Total Faculty and Staff by COE Department as of December 2019)

As the COE is located at a neutral site away from both campuses many faculty, staff, and students do not spend a lot of their time at their home campus during "normal business" hours. 
To alleviate headaches of driving to and from campuses and fighting the parking battles each school provides buses that run to and from the $\mathrm{COE}$ and their main campuses during the day.

\section{Background on the FAMU-FSU College of Engineering Library}

The COE Library is housed within Building A of the COE space. Its mission is to enhance the learning, teaching, research, and service activities of all COE community users. In furtherance of gaining more insight into the history of the COE Library, the authors conducted an in-person interview with a former COE Library Associate from 2006-2018. This individual has since been promoted to STEM Service Desk Manager, which includes the COE Library [14]. In 2011, the COE space underwent a redesign to expand available study space for students and to open up the overall flow of the space based on previously conducted student surveys. Originally housed in one room, the COE Library had posters covering windows, a reserves area, a service desk, and approximately 25 tightly scrunched seats for students. It was thought by many COE users that the space was a storage room, due to the inability to see into the room itself. Through the redesign, the posters were moved allowing everyone to see into the library space and the staff at the time worked with the FSU Libraries Dean and the COE Dean to secure an additional room across the hall that would allow more seating for students to study. This two-room space created 42 seats for students to study and do group work with room to move around. FSU Libraries and FAMU Libraries worked together to provide necessary equipment for the redesigned space, such as computers, scanners, and copiers. After this redesign, students requested additional quiet study space and worked with the COE Dean to provide funding for two classrooms located next to the COE Library to function as "Quiet Library Space" from the hours of six o'clock p.m. through midnight, Monday nights through Thursday nights. No food, and no cell phones are allowed in these spaces and a dedicated COE student worker monitors the room usage.

a)

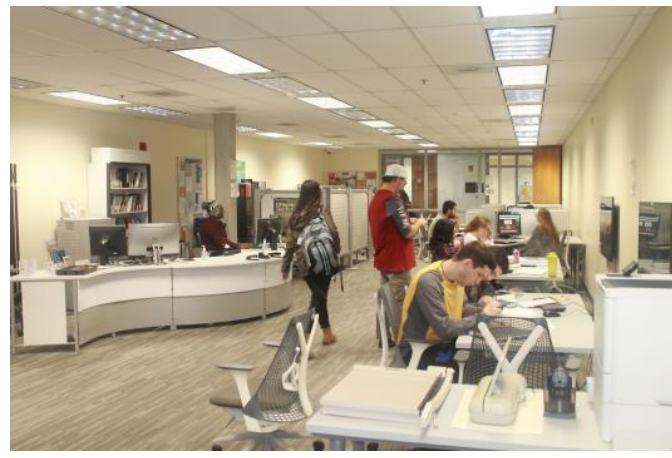

b)

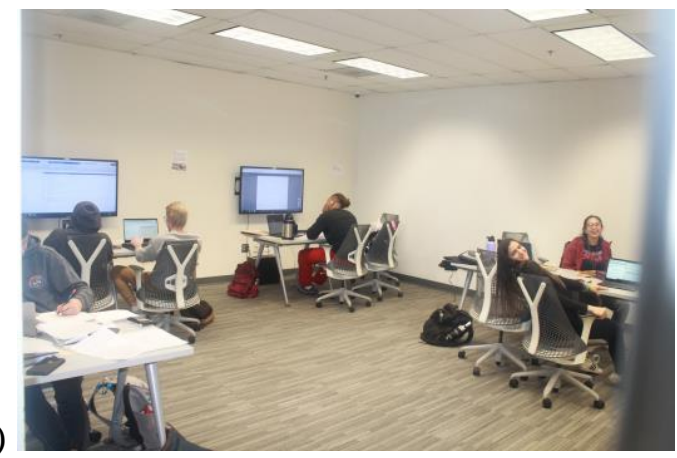

(Figure 1a: Main COE Library space; Figure 1b: additional COE Library space)

The main book and collections for engineering are housed at both the Paul A. M. Dirac Science Library, on the FSU main campus, and in the Coleman Library, on the FAMU main campus. The Engineering Library is a satellite for both university libraries and houses a small collection along with extensive access to electronic collections (laptops, cameras, etc.). Materials not available in the physical COE Library space or through a main campus library can be secured using the Interlibrary Loan or UBorrow services. UBorrow is a service that faculty, staff, and students can use to request physical materials directly from participating libraries within Florida's state university and college systems [15]. It is unmediated and has a generally quick turnaround, 
though eBooks are excluded from this service. One service that FSU's University Libraries provides to its faculty, staff, and graduate students with appointments is the Library Express Delivery Service (LEDS). This service delivers library materials to individual offices and departments which has been especially helpful to constituents located at the COE campus as it saves faculty the headache of timing the busses or finding parking on the main campus [16].

After a few iterations of library staffing models over the years, the COE Library is currently serviced by two engineering subject librarians from FSU Libraries, an engineering desk coordinator from FSU Libraries, and several student library workers through both FAMU and FSU. The two subject librarians are also subject librarians for multiple STEM disciplines on the FSU main campus, but they provide weekly office hours at the COE during the academic school year. COE constituents receive research assistance on an as needed basis through in-person meetings, online meetings, email, and phone calls, along with in-class instruction upon request.

Without a librarian housed in the COE Library or within easy walking distance of their building it can become easy for faculty and staff to feel detached from their campus library as they are not within their physical space [17],[18]. In an effort to bring the library to those at COE the authors have been working with their own brand of embedded librarianship. As a 2010 article by Drews and Hoffman describe embedded librarians as librarians who are physically or virtually present in the space their users take up [19]. The authors of this paper wanted to create a connection and bring the library to the COE users through their outreach efforts.

\section{Evolution of FAMU-FSU College of Engineering Library Outreach}

As mentioned previously, there have been multiple staffing models used with the COE Library, but the authors are going to focus on models they actually witnessed and/or were a part of. This means that the authors focus on how outreach has grown over the past three years. While it may seem to be a smaller period of time, great strides and lessons were learned over the course of these three years. The authors also feel that they could not fully explain previous years outreach efforts as neither author was a part of the FSU Libraries team prior to January of 2017.

\section{Branding of Office Hours}

Office hours have been a touchstone for outreach growth over the past three years. This was a new service to COE provided by FSU Librarians as the FSU Libraries STEM Librarian team grew. This service began as a weekly walk-in service for any and all COE faculty, staff, and students. The COE Library referred to this time as "office hours," which led to a lot of confusion amongst COE students as they were unsure how the COE Librarians could provide help for classes. A generic, "Ask Me Questions" sign was used (modeled off of another office hours sign used by FSU Libraries) to mark the location of the librarian providing the office hours service. Other than the day and time remaining consistent, the librarian providing office hours and the location within the COE building would rotate on a weekly basis. The relocation of office hours location from inside the COE Library itself to within the larger COE building itself was twofold: first, it allowed more space for actual consultations and second, it helped increase visibility for the COE Librarians and the service. 
This model was then revised over the summer of 2018 into a newly branded period called, "The Librarian Is In." Figure 2a shares a picture of the new branding sign that was used. By using the terminology "The Librarian Is In," instead of "office hours," there seemed to be less confusion from students over the service. Overall walk-in contact points with faculty, staff, and students increased over the course of the academic year. The librarians maintained a set day and time for these office hours, but continued to rotate both the location within the COE buildings and the librarians present. Based on feedback from a COE department chair, the librarians also began emailing the COE listservs each week to announce when the librarians were actually in during Spring 2019. The main point of contention for this branding strategy came not from the name but from the use of FSU colors for the sign. Because of the joint nature of this College, feedback was provided to FSU Libraries that the use of FSU colors for office hours unintentionally communicated to students that only FSU students could be helped during these times. The librarians were always willing to help any and all participants, but this miscalculation in branding for this service unintentionally harmed the overall outreach effort.

Going into the third year of this service, the COE Librarians used the summer of 2019 to work on both the branding and the marketing of office hours. The COE Librarians consulted with the COE Director of Marketing \& Communications to work on how to better solicit the office hours to make them seem more approachable, while also spreading the word further to increase this walk-in service time's use. The biggest change was to use a neutral color palette on the marketing signage itself, which resulted in the change from FSU colors to Blue, the same color palette used by the COE administration, as shown in figure 2b. The words, "All Engineering Students are welcome!" were also added to the sign to further communicate that the librarians were actually in for them. Emails continued to be sent across COE listservs at office hours each week. This year, the COE subject librarians have continued to split who attend office hours, but the other STEM librarians are only used on an as needed basis. By providing further consistency in the faces that faculty, staff, and students see, this has strengthened relationships within the COE itself.

a)

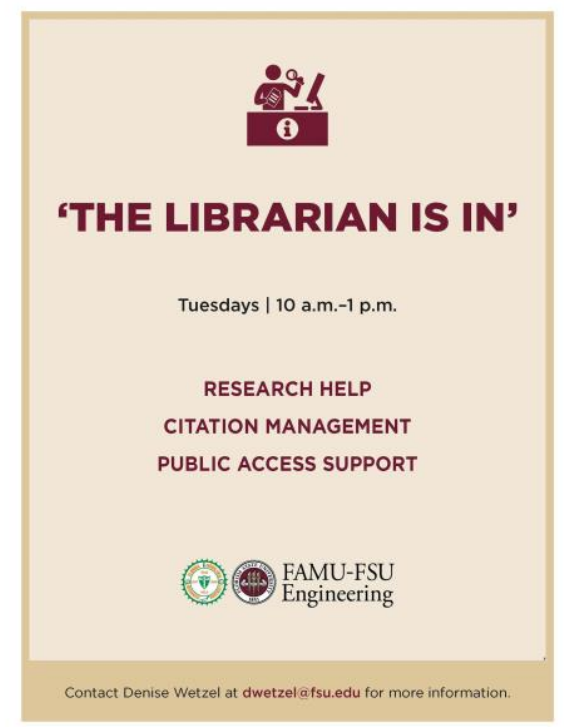

b)

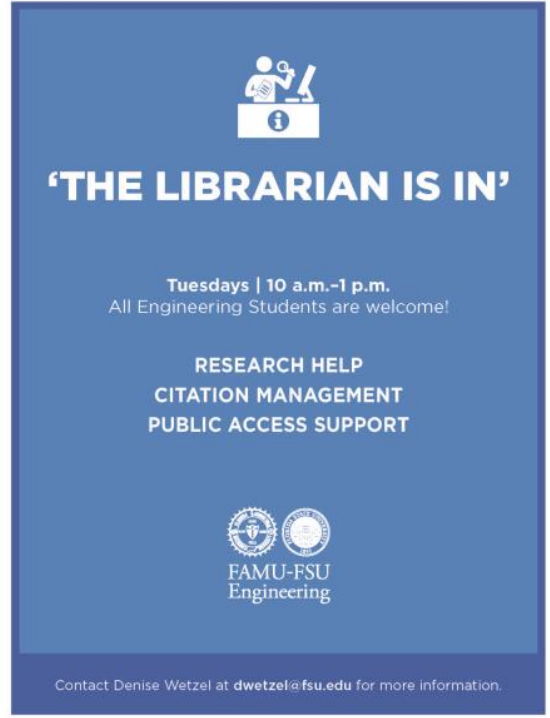

(Figure 2a: 2018-2019 “The Librarian Is In” marketing using FSU colors; Figure 2b: 2019-2020 "The Librarian Is In" marketing using neutral COE colors) 
While this year is incomplete as of January 2020, the overall data shows a positive trend in the number of consultations during these office hours. Table 5 shows how both questions during office hours and COE consultation numbers have increased over the past three years. The authors feel that this is directly a result of the increased outreach provided to the COE constituents over the past three years. It is important to note that office hours were not held during the summers of 2017, 2018, or 2019. Plans are currently being formulated to offer this service during part of the upcoming 2020 summer, as faculty have made this request.

\begin{tabular}{|c|c|c|c|}
\hline Academic Year & $\begin{array}{c}\text { COE Office } \\
\text { Hours' Questions }\end{array}$ & Academic Year & COE Consultations \\
\hline $\begin{array}{c}\text { August 1, 2017 } \\
\text { - July 31, 2018 }\end{array}$ & 3 & $\begin{array}{c}\text { August 1, 2017 } \\
\text { - July 31, 2018 }\end{array}$ & 41 \\
\hline $\begin{array}{c}\text { August 1, 2018 } \\
\text { - July 31, 2019 }\end{array}$ & 27 & $\begin{array}{c}\text { August 1, 2018 } \\
\text { - July 31, 2019 }\end{array}$ & 93 \\
\hline $\begin{array}{c}\text { August 1, 2019 } \\
\text {-January 23, } \\
\text { 2020* }\end{array}$ & 22 & $\begin{array}{c}\text { August 1, 2019 } \\
\text { - January 23, } \\
2020 *\end{array}$ & 108 \\
\hline
\end{tabular}

(Table 5: Office Hour Questions and COE Consultations from August 1, 2017 through January 23, 2020. The * indicates an incomplete academic year.)

\section{Creating the Faculty Postcard}

During the spring and summer of 2018, FSU Libraries began creating a marketing campaign geared to spreading our services out to all STEM faculty across the main FSU campus. This campaign culminated in the creation of STEM Librarian postcards, featuring the pictures and contact information for all four STEM Librarians on the front with curated information on the reverse side. This information provided focused on four areas of support services for the faculty: research, instructional, public access, and citation management.

In order to mirror these marketing efforts, the COE Librarians also created a targeted $\mathrm{COE}$ postcard for COE faculty. This postcard featured only the two COE Librarians, but used similar content on the informational side in regard to support services. Figures $3 \mathrm{a}$ and $3 \mathrm{~b}$ shows both sides of the current COE postcard distributed in August 2019. 

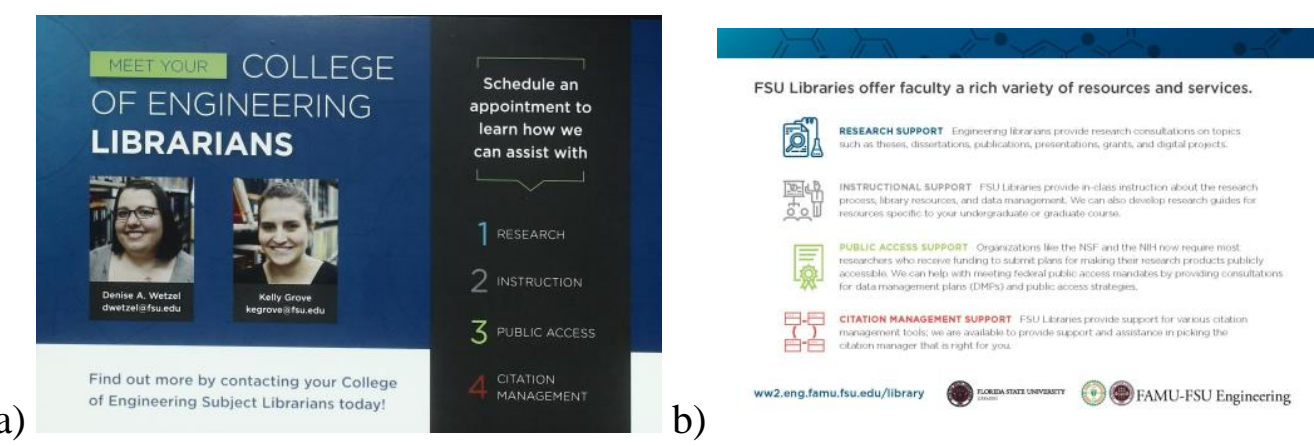

b)

(Figure 3a: Front of current COE Postcard; Figure 3b: Back of current COE Postcard)

During both August 2018 and August 2019, these postcards were distributed to all COE faculty through faculty mailboxes. Additional copies of the postcard are kept at the COE Library Circulation Desk and provided to faculty after meeting with their librarians during office hours. As with the creation of signage for the weekly office hours, a COE neutral color scheme was utilized in hopes of attracting faculty assigned to both institutions to feel that the COE Librarians are available to everyone, not just FSU employees and students.

\section{Creating Workshops that Work}

When it comes to workshops, a refrain often heard in libraries is, "but how can we get them/students/people to attend?" When we began hosting workshops at COE during Fall 2018, no one attended. We dipped our toes into the proverbial workshop pond with a series of four workshops on how to use COE library resources: two introduction workshops and two advanced workshops. Figure 4a shows this initial workshop flyer. It was disappointing to find that seemingly there was no interest.

The COE Librarians then spent Spring 2019 exploring and speaking with faculty to create a new series that met the needs of COE students and faculty. The pilot workshop for this exploration occurred in April 2019 with the help of a FSU colleague; it focused on the use of Tableau for data visualization. For this workshop, we created marketing materials and pushed materials out on social media. Figure $4 \mathrm{~b}$ shows an example of the Instagram graphic used for promotion of this workshop. Attendance for this workshop was so great, it had to move to a larger space at the last minute to accommodate the increased audience size. This felt like a home run and the success of this workshop propelled the COE Librarians through Summer 2019 into a new series beginning in Fall 2019.

For Fall 2019, the COE Librarians premiered our new series with a focus of providing workshop content that would support COE student needs. The intended audience for these workshops is any and all COE constituents, but the vast majority of attendees have been both undergraduate and graduate students. This series focused on tools such as: Tableau, MATLAB, and LaTex \& BibTeX, for three of the workshops, with patent searching also featured due to the need to support student success. The COE Librarians also worked with the COE Marketing Team to feature these workshops on digital signage through the COE building, on the COE calendar of events, and the posting of physically printed posters. Figure 4c shows an example of the signage used to promote these workshops. These workshops were linked on both the FSU Library website, the COE Library website, and across different social media platforms. Also, handbill- 
sized flyers were placed in the COE Library. Across the board, these workshops filled their physical space and even led to waitlist registrations due to student interest.

After the overwhelming success of this Fall 2019 series, the COE Librarians worked with their colleagues to create a new Spring 2020 workshop series. This series features only one tool, MATLAB, but it does provide content based on student and faculty consultation and classroom requests in the form of three different sessions on Measuring Research Impact, Engineering Entrepreneurship, and Patent Searching. Figure 4d shares this workshops series' digital flyer. Once again, the COE Librarian have worked with the COE Marketing Team to feature these workshops on digital signage through the COE building, on the COE calendar of events, and the posting of physically printed posters. Once again, these workshops were linked on both the FSU Library website, the COE Library website, and across different social media platforms. Also, handbill-sized flyers were placed in the COE Library. An additional step taken has been this semester to email the department chairs with the workshop series' flyers and a brief message in an effort to get more visibility to COE researchers in building outside of the main COE building. With the increase awareness of workshops and the new targeted method the subject librarians have received multiple from different public parties who are not an engineering student or faculty member, but have a connection to the COE in some way.

a)

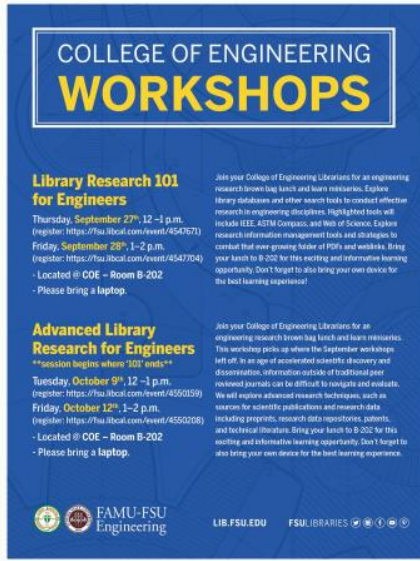

b)
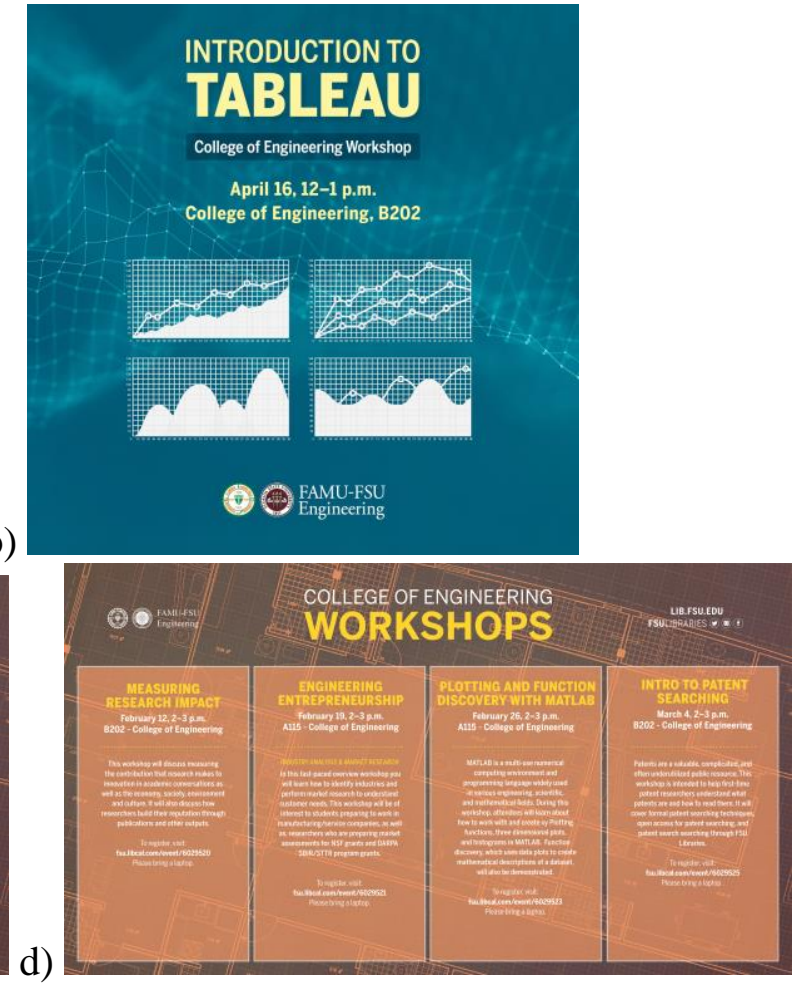

c)

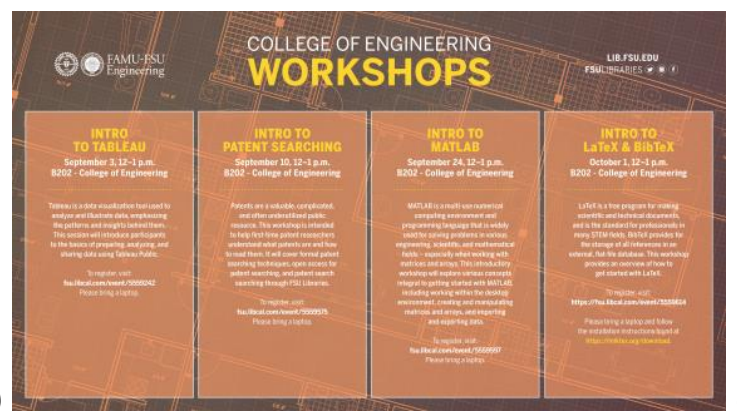

Marketing Flyer; Figure 4b:COE Spring 2019

(Figure 4a: COE Fall 2018 Workshop Series Marketing Flyer; Figure 4b:COE Spring 2019
orkshop Instagram Image; Figure 4c: COE Fall 2019 Workshop Series Digital Sign; Figure 4d: COE Spring 2020 Workshop Series Digital Sign) 
This evolution of workshop series, from unsuccessful to success shows that FAMU-FSU COE constituents have an interest in library workshops. Table 6 shows a listing of COE attendance numbers by workshop name and academic semester. Because the workshops are still in process for the Spring 2020 semester, those workshop numbers are not available at this time. The main factor of success came down to content. The generic, this is how you use your library was a repeat of what is seen in many instruction sessions and not appealing to potential attendees. These workshops work because the content works for the needs of this COE.

\begin{tabular}{|c|c|c|c|c|}
\hline Academic & \multicolumn{4}{|c|}{ Workshop Name and Number of Attendees } \\
\hline \multirow[t]{2}{*}{ Fall 2018} & $\begin{array}{l}\text { Library Resources } \\
101 \text { for Engineers }\end{array}$ & $\begin{array}{c}\text { Library } \\
\text { Resources } 101 \\
\text { for Engineers }\end{array}$ & $\begin{array}{c}\text { Advanced } \\
\text { Library Research } \\
\text { for Engineers }\end{array}$ & $\begin{array}{c}\text { Advanced } \\
\text { Library Research } \\
\text { for Engineers }\end{array}$ \\
\hline & 0 & 1 & 0 & 0 \\
\hline \multirow[t]{2}{*}{ Spring 2019} & \multicolumn{4}{|c|}{ Introduction to Tableau } \\
\hline & \multicolumn{4}{|c|}{ * } \\
\hline \multirow[t]{2}{*}{ Fall 2019} & $\begin{array}{l}\text { Introduction to } \\
\text { Tableau }\end{array}$ & $\begin{array}{l}\text { Intro to Patent } \\
\text { Searching }\end{array}$ & $\begin{array}{l}\text { Intro to } \\
\text { MATLAB }\end{array}$ & $\begin{array}{l}\text { Intro to LaTeX } \\
\text { and BibTeX }\end{array}$ \\
\hline & 7 & 17 & 15 & 4 \\
\hline \multirow[t]{2}{*}{ Spring 2020} & $\begin{array}{c}\text { Measuring } \\
\text { Research Impact }\end{array}$ & $\begin{array}{c}\text { Engineering } \\
\text { Entrepreneurship }\end{array}$ & $\begin{array}{l}\text { Plotting and } \\
\text { Function } \\
\text { Discovery with } \\
\text { MATLAB }\end{array}$ & $\begin{array}{l}\text { Intro to patent } \\
\text { Searching }\end{array}$ \\
\hline & $* *$ & ** & ** & $* *$ \\
\hline
\end{tabular}

(Table 6: Workshop attendance for COE workshops by academic semester. * indicates that the workshop number of attendees not recorded. $* *$ indicates an incomplete academic semester.)

\section{Conclusion}

As the Subject Librarians for COE the authors have identified a few areas of growth they would like to work towards in the forthcoming semesters. One area would be to increase the amount of engineering class instruction invitations. Some possible targets to increase instruction include targeting the researchers in charge of research groups as this would allow the authors to talk to groups of students actively participating in research projects with their professors and/or instructors. Additionally, the COE librarians would like to increase their involvement with the 
more of the introductory-level courses. The authors believe that if the students see them early on in their engineering education they may be more likely to ask for help when they see the librarians during open office hours.

A second area of growth would be to increase the types of workshops offered. The current plan is for each librarian to learn new tools as time allows in order to keep the rotation fresh. Also to leverage the expertise of other librarians on campus to fill in knowledge gaps. One idea which has not been fully explored is a survey of COE teaching faculty in order to build upon their classroom needs. Due to the varying majors in the College, this could possibly lead to a large list of workshop topics to build further expertise in.

The authors believe that their growth in outreach efforts have directly impacted the overall relationship that FSU Libraries has with the FAMU-FSU College of Engineering. Even though not every iteration of an outreach effort has been successful, they have all been learning experiences for the COE Librarians. All details, including the colors used on signage, can be important for the overall success of an outreach campaign. This case-study shares these experiences with the reader and hopes to provide a voice in the landscape of engineering outreach, especially for multi-institutional librarians. 
References:

[1]C. G. Pickvance, "Four varieties of comparative analysis," Journal of Housing and the Built Environment, no. 16, pp. 7-28, 2001, doi:10.1023/A:1011533211521.

[2]"UM-SJTU Joint Institute - The College of Engineering." [Online]. Available:

https://www.engin.umich.edu/admissions/international/joint-institute/. [Accessed: 24-Jan-2020].

[3]"Pitt Announces Partnership With China's Sichuan University to Establish Joint Engineering Institute | University of Pittsburgh News." [Online]. Available:

http://www.news.pitt.edu/Pitt_Sichuan_Partnership. [Accessed: 24-Jan-2020].

[4]"Joint Co-op Institute | University Of Cincinnati.” [Online]. Available:

https://ceas.uc.edu/real-world-learning/global-opportunities/joint-engineering-co-op-

institute.html. [Accessed: 24-Jan-2020].

[5]"Georgia Tech and the University of Stuttgart Establish Joint MS Degree | The George W. Woodruff School of Mechanical Engineering." [Online]. Available:

http://me.gatech.edu/featured jointmsmestuttgart. [Accessed: 24-Jan-2020].

[6]"Joint Programs | Undergraduate Academic Affairs | Illinois Institute of Technology."

[Online]. Available: https://web.iit.edu/ugaa/joint-programs. [Accessed: 24-Jan-2020].

[7]“Combined Plan Program Experience | Columbia Undergraduate Admissions." [Online]. Available:

https://undergrad.admissions.columbia.edu/learn/academiclife/engineering/combined-planprogram. [Accessed: 24-Jan-2020].

[8]"Undergraduate Engineering Partnerships with Other Institutions | College of Engineering | NC State University." [Online]. Available: https://www.engr.ncsu.edu/admissions/transferadmissions/partnerships/. [Accessed: 24-Jan-2020].

[9]M. T. Jackson, “The Atlanta University Center: A Consortium-Based Dual Degree Engineering Program," New Directions for Higher Education, no. 138, pp. 19-25, 2007, doi: 10.1002/he.251.

[10]A history of the Florida A\&M University-Florida State University College of Engineering 1982-2007: The silver anniversary, Tallahassee, FL: Sentry Press, 2007.

[11]J. Bean, R. Dixon, M. Harrington, R. Warder, and B. Points. "FAMU-FSU Joint College of Engineering study: Preliminary report," CBT University Consulting, Prepared for The Florida State University System Board of Governors. Sacramento, CA. Available: http://www.famu.edu/BOT/Preliminary\%20Report\%20of\%20CBT\%20UC_2.pdf, Nov, 19, 2014.

[12]Office of Institutional Research, "Fact Book", Ir.fsu.edu. https://ir.fsu.edu/factbook.aspx (accessed January 24, 2020). 
[13]Office of Institutional Research, "Fact Book 18-19", Ir.fsu.edu.

http://www.famu.edu/index.cfm?oir\&FactBook18-19 (accessed January 24, 2020).

[14]C. Harley, "In-person interview with Cynthia Harley: History of FAMU-FSU COE Library," 28-Jan-2020.

[15]Florida State University Libraries, "UBorrow," lib.fsu.edu.

https://www.lib.fsu.edu/services/uborrow (accessed January 27, 2020).

[16]Florida State University Libraries, "LED: Library Express Delivery Service Request," lib.fsu.edu.https://www.lib.fsu.edu/form/led-library-express-delivery-service-request (accessed January 27, 2020).

[17]T. Matava, D. Coffey, and J. Kushkowski, "Beyond Library Walls: Embedding Librarians in Academic Departments," Public Services Quarterly, vol. 6, no. 2-3, pp. 165-173, Sep. 2010, doi: $10.1080 / 15228959.2010 .497835$.

[18]P. Rudin, "No Fixed Address: The Evolution of Outreach Library Services on University Campuses," The Reference Librarian, vol. 49, no. 1, pp. 55-75, Aug. 2008, doi: $10.1080 / 02763870802103761$.

[19]K. Drewes and N. Hoffman, "Academic Embedded Librarianship: An Introduction," Public Services Quarterly, vol. 6, no. 2-3, pp. 75-82, Sep. 2010, doi:10.1080/15228959.2010.498773. 